\title{
DOI: 10.7596/taksad.v9i3.2780
}

Citation: Yeremenko, O., Chystiakova, I., Biriukova, L., \& Petrenko, M. (2020). Training of Future Musical Art Teachers: An Ethnocultural Approach. Journal of History Culture and Art Research, 9(3), 127-138. doi:http://dx.doi.org/10.7596/taksad.v9i3.2780

\section{Training of Future Musical Art Teachers: An Ethnocultural Approach}

\author{
Olha Yeremenko ${ }^{1}$, Iryna Chystiakova ${ }^{2}$ \\ Larysa Biriukova ${ }^{3}$, Maryna Petrenko ${ }^{4}$
}

\begin{abstract}
The article reveals theoretical and methodological foundations of implementing the ethnocultural approach in the process of future musical art teachers' professional training. The results of the study have shown that implementing the ethnocultural approach in art education is one of the requirements of the new education paradigm. It is proved that in the process of future musical art teachers, professional training should be taken into account the developmental capabilities of folk music and peculiarities of ethno-musical education development. The article highlights the principles, which regulate the process of future musical art teachers' professional training: ethnocultural basis of students' professional skills formation; using national samples of musical art as learning repertoire; involving students in various types of musical and aesthetic activities, especially in the study of various works of national musical art; personality-centered organization of the educational process; inclusion of ethnocultural component in courses of historical-theoretical and methodological cycles; effective use of various forms of ethno-musical activity.
\end{abstract}

Keywords: Ethnocultural approach, music education, teacher training, professional training of a musical art teacher.

\footnotetext{
${ }^{1}$ D.Sc. in Education, Professor, Sumy State Pedagogical University named after A.S. Makarenko. e-mail: yaremenko1969@ukr.net

2 Ph.D. in Education, Associate Professor, Sumy State Pedagogical University named after A.S. Makarenko. e-mail: pedagogyniversitet2017@gmail.com

3 Ph.D. in Education, Associate Professor, Sumy State Pedagogical University named after A.S. Makarenko.e-mail: lara123455@gmail.com

${ }^{4}$ Ph.D. in Education, Associate Professor, Sumy State Pedagogical University named after A.S. Makarenko.e-mail: mariina.petrenko@gmail.com
} 


\section{Introduction}

In the modern world, there is an objective need to train socially responsible people who can successfully operate in polyethnic and multicultural spaces. These people will be able to revive the culture of different ethnic groups, preserving their cultural identity in the context of globalization. There is no doubt that difficulties in achieving this task are caused by the complexity of the ethnic picture of the world and the political map of the planet. In this regard, we believe that socio-cultural activities of the world community should be intensified, aimed at ensuring civilized coexistence, friendly interaction, humane communication of ethnic groups, formation of their ethnic identity, ethnocultural tolerance in conditions of preserving, developing national cultures and involving youth in these processes.

Therefore, it is important in this context to use an ethnocultural approach in the education system at all levels. We would like to note that ethnocultural orientation of education is reflected in numerous documents, which emphasize the importance of forming in the child a culture of dialogue, a culture of life in mutual understanding, peace and harmony between all peoples, ethnic, national, religious groups, representatives of different political and religious views and cultural traditions (Law of Ukraine "On education", 2017), forming civic culture and culture of democracy (Law of Ukraine "On complete general secondary education", 2020).

In this regard, the use of the ethnocultural approach to education is especially important. Its implementation will allow individuals to master the culture of their people, successfully interact with other ethnic cultures based on tolerance, humanity, and dialogue, focus on conscious, socially active behavior.

In our opinion, in the first place, the ethnocultural approach should be implemented in the educational field "Art", in particular, "Music". It is recognized as one of the most important means of socialization of the individual in the process of forming universal, national, and ethnic values based on vivid feelings and images, involving him/her in active interethnic and intercultural communication, interaction, and cooperation. For the most part, these values are revealed in folk music, which has concentrated the social norms of interaction, spiritual and moral qualities, and aesthetic ideals of the ethnos. Supported by vivid emotions, expressive melodies, they can have a strong influence on the inner world of the individual, stimulate his/her life on the basis of humane treatment of different ethnic group members. The soul of the nation, its history, customs, recoded into musical intonations, will become part of its worldview, determine the formation and development of a socially active ethnocultural personality.

\section{Literature Review}

Various aspects of future musical art teachers' professional training have been considered in the studies of such domestic scientists as: H. Nikolai, T. Tanko, V. Cherkasov et al. (history of musicpedagogical education development); A. Kozyr, O. Oleksiuk, H. Padalka, O. Rostovskyi, O. Rudnytska, O. Shcholokova et al. (theoretical concepts of musical art teachers professional training); N. Murovan, N. Seheda (continuing education of music teachers); T. Aheikina-Starchenko, O. Bobliienko, K. Kabryl, M. Mykhaskova, O. Rybnikov et al. (competence approach in future musical art teachers professional training); A. Bolharskyi, T. Zhyhinas, N. Mozhaliova, N. Ovcharenko, O. Plokhotniuk, T. Reizenkind et al. (future teachers professional training for music-pedagogical activities).

Foreign scientists were also actively engaged in the study of this problem. Thus, the historical approach to music-pedagogical education development was considered by M. Kamba, M. Ros; theoretical and methodological foundations of music teachers professional training were studied by $\mathrm{E}$. Rohlfs, R. Thomas, J. Finney, A. Jacoby; methodological and organizational principles of future music 
teachers professional training were specified by J. Cooksey, J. Paynter; formation of future music teachers' professional competence became the subject of scientific research by A. J. Kruse, E. N. Scott, L. C. Thornton.

Ethnocultural orientation of education determines the relevance of substantiation of the ethnocultural approach to education, namely to future musical art teachers training. In this regard, scholars are increasingly focusing on the implementation of the ethnocultural approach in the process of future musical art teachers' preparation to perform professional activities. Therefore, this approach in its various aspects was studied by such scientists as L. Mykulanynets, S. Sieriakova, L. Solyar, S. Fedorova, J. Khashtyrov, N. Shahaieva.

O. Berezyuk (2015), O. Hurenko (2005), O. Milanova (2011), S. Sieriakova (2002), N. Sidelnyk (2012), S. Fedorova (2006), Qiao Ji (2016) focused on peculiarities of future teachers' ethnocultural competence formation. The process of musical art teachers' ethnocultural competence formation was highlighted by Lu Lu (2014), L. Solyar $(2016,2018)$. Other aspects of the issue under investigation were considered by A. Kozyr (2018) (ethnocultural context of training future music and choreography teachers); Xu Tszyayuy (2017) (methodological principles of future music teachers ethnocultural training); O. Khoruzha (2008) (ethnocultural and ethnopedagogical aspects of music teachers professional training).

According to L. Karpushyna, an ethnocultural approach is based on the principle of ethnoculturalism, dialogue of cultures, cultural creativity, tolerance, connection of education with ethnocultural environment based on key ethnocultural traditions in education in order to form an ethnocultural personality (Karpushyna, 2010).

L. Solyar (2018) notes that ethnoculture in Ukraine is determined primarily by the ethnic behavior of the most numerous and titular Ukrainian nation, which has historically acted as the main consolidating factor in statehood. However, each of the national groups, creating integration processes, diversifies the forms of its manifestation, mainly in the direction of regional diversity of ethnocultural basis.

We agree with the domestic researcher A. Kozyr, who after S. Honcharenko (2011) proclaims the idea that the ethnocultural context of future music and choreography teachers' training allows to determine the relationship between education and culture as an environment in which the student becomes a cultured person. This means that the cultural core of the curriculum consists of universal, national, and regional cultural values. In this context, the student should be perceived as a free, holistic individual capable of independent choice of values, self-determination in the world of culture and selfrealization (Kozyr, 2018, p. 43).

However, despite the increased interest in the problem of implementing the ethnocultural approach in future musical art teachers' training, a generalized study on this issue has not yet been carried out.

Thus, the aim of this article is to clarify the theoretical and methodological foundations of the ethnocultural approach in future musical art teachers' training.

\section{Methodology}

Based on the analysis of theoretical and methodological ideas of scientists in various fields, including culturologists, art critics, teachers, as well as rethinking of the essence of ethnocultural approach to art education in general and music in particular, we have developed a concept of implementing the ethnocultural approach in future musical art teachers training. The concept is based on scientific approaches, formulated at such levels of methodology as philosophical (axiological, 
praxeological); general scientific (systems, humanistic, personality-centered) and specific scientific (culturological, sociocultural).

The axiological approach envisages actualizing teachers' methodological, theoretical, and applied knowledge about values, their nature, mechanisms of development and methods of functioning, as well as professional and pedagogical values that characterize professional development and self-improvement of the modern teacher (Zhyhinas, 2016).

The axiological approach is based on the idea of man as a value and a main goal of the social and educational process. Therefore, we are convinced that the ethnocultural basis of future musical art teachers professional training is constituted by universal values, values of ethnic groups, and values of folk pedagogy of a particular ethnic group. Taking into account the above mentioned, we'd like to emphasize that values, methods, and tools of folk pedagogy are important for the professional training of future musical art teachers.

The praxeological approach is a set of provisions, practical implementation of which directs the process of teachers' preparation for the improvement of their practical activities with a focus on maximum expediency. I. Kolesnykova and O. Tytova (2005) believe that this approach allows not only determining the norms of activity, but also offering recommendations for optimizing actions, identifying feasibility, rationality of pedagogical actions and operations in order to optimize methodological activities of future music teachers. It is characterized by the unity of the ratio of knowledge and practice.

The praxeological approach involves organization of future musical art teachers' professional activities and planning further actions based on ethnocultural approach, with signs of reality, specificity, accuracy, and absence of contradictions of the chosen guidelines and goals.

Thus, the praxeological approach in future musical art teachers professional training on an ethnocultural basis means understanding of its functionality, effectiveness, determining the appropriateness of the teachers' actions, identifying those techniques, methods, and operations that do not satisfy, finding out the causes of inefficiency, studying opportunities, potential and unused reserves, making proposals to increase the effectiveness of such training using ethnocultural material.

Thus, agreeing with Xu Tszyayuy, we'd like to note that acquiring ethnocultural values by the future musical art teacher in the process of professional training directs his/her personality towards realization in further professional activity of the educational ideal of folk pedagogy, which is one of the most important results of ethnocultural training (Xu Tszyayuy, 2017).

We believe that the systems approach to substantiation of all components of the educational process embodies methodological guidelines for the implementation of relevant doctrines of education.

According to B. Lomov, the basis of the systems approach is formed by six key positions: multidimensionality; scale; differentiation; multilevel construction; various properties; dynamism (Lomov, 2003).

Thus, the systems approach involves designing activities for the selection of ethnocultural material, introducing forms and methods of future musical art teachers training in pedagogical HEIs on ethnocultural basis, as well as consistent implementation of ethnocultural approach in practice. In our opinion, it enhances ethnocultural thinking and meaning-creating activity. The purpose of the ethnocultural approach is to prepare a highly educated person capable of creative activity, ready for self-realization and self-determination in professional, social, and personal spheres, free from negative ethnocultural stereotypes, a citizen of the world and a member of the world community. 
The study and analysis of pedagogical achievements of education theorists and practitioners on the implementing ethnocultural approach in future musical art teachers professional training made it possible to understand it in the context of forming the value attitude of future teachers to art, pedagogical and research activities, their ability to deep rethinking of human values, embodied in artistic images and adequate assessment of artistic achievements in the interpretation of music, consequences of teaching and results of research.

We agree with the domestic researcher $\mathrm{H}$. Padalka, who believes that the personality-centered approach in art education is based on orienting the process of teaching art disciplines towards personality development. The author emphasizes that by involving in artistic activity, the teacher takes care, first of all, of his/her student's personality formation. At the same time personality formation does not mean opposing this task to assimilation and development of special artistic knowledge and skills, abilities, artistic experience; assertion of the subjective role of the student in the process of art education (Padalka, 2010, p. 72).

Thus, the use of a personality-centered approach involves taking into account the importance of the personal-value and individual-personal orientations of learning. In the process of future musical art teachers' professional training, learning in the context of this approach is associated with activity, creative need of the student in the versatile comprehension of the musical work, with his/her emotional reflection, evaluation, creative self-expression, comparison, rethinking according to personal internal experience.

Our choice of culturological approach is conditioned by the orientation of modern education towards the cultural context and presupposes an objective connection of man with culture as a system of values. In addition, it considers culture as a source and basis of the educational process.

The culturological approach in future musical art teachers professional training is aimed at ensuring their readiness for music-pedagogical activities on a cultural basis, awareness of themselves as bearers of culture, endowed with desire and ability to bring up students as bearers and creators of culture (Protsiuk, 2015, p. 127).

It is indisputable that the culturological approach expands research boundaries, provides a panoramic multidimensional view and a poly-systemic explanation of the essence of cultural problems, values, and components of modern education in general and music education in particular. Within the framework of culturological approach, professional training of future musical art teachers is considered as a culture-forming educational process of gradual mastering of the content of pedagogical culture during acquiring the profession, in which the student and the teacher realize themselves as subjects of professional pedagogical culture.

Thus, based on the position of culturological approach, we emphasize the importance of creating appropriate conditions for interpenetration and mutual enrichment of different cultures. Since in the process of acquainting students with learning material, including ethnocultural, they become aware of differences between cultures, form a tolerant attitude to culture, a sense of pride for their own national cultural heritage.

The ethnocultural context of training future musical art teachers encompasses the sociocultural relevance of this process. This aspect involves making changes to the system of professional skills formation in accordance with the needs of society. Motivation for innovations is formed under the influence not so much of the internal drivers of the educational process, but due to awareness of the essence of external factors, in particular, the level and features of modern artistic, aesthetic, psychological, and pedagogical culture. The ethnocultural context of future musical art teachers' training is aimed at eliminating the contradictions between the students' educational and professional 
needs and society's requirements for them as well as changing social situations. It orients the educational process towards adaptive approaches that would allow taking into account new cultural approaches (Kozyr, 2018).

\section{Discussion}

First of all, it should be noted that awareness and belonging of a person to a certain nationality as determinants of personal destiny are important for both Ukrainian and global human culture. National affiliation is not a suprapersonal abstraction, but a "need of the soul" - an immanent manifestation of the individual spirit in the context of individual development (Ivanova, 2005).

A review of modern philosophical and psychological-pedagogical literature gives grounds to state strengthening of ties between education and culture, constant growth of attention to ethnocultural problems of education and upbringing. This approach, in our opinion, provides a multifaceted and multidimensional view of the essence of ethnocultural problems, values, and components of modern education.

The ethnocultural orientation of art education specialists training is one of the requirements of the new education paradigm, which will enrich their ethnocultural space, focus on mastering the basics of the worldview, awareness of their own destiny in modern sociocultural space. Thus, the ethnocultural orientation of education determines the relevance of substantiating the ethnocultural approach to education, in particular music one.

We believe that the ethnocultural approach to education is based on the principles of ethnoculturalism, cultural creativity, tolerance, dialogue of cultures, connection of education with ethnocultural educational practice, and ethnocultural environment. It takes into account key ethnocultural traditions in education aimed at the formation of an ethnocultural personality in the course of socialization and enculturation. Such a personality is characterized by a developed ethnic identity, personal ethnic culture, tolerance, and basic socio-cultural identities, he/she is capable to perceive and retransmit ethnoculture, ready for the dialogue of cultures. Thus, the ethnocultural approach to education determines the direction of the process of future musical art teachers' professional training at retransmitting to the younger generation of the folk music culture.

As a result of the analysis of scientific achievements of art critics, education theorists, and practitioners, we have identified the developmental potential of folk music, namely:

- it is based on ethno-musical traditions, which are an inexhaustible source of folk wisdom and huge intellectual wealth; they act as systems of national and aesthetic values, allow to develop spiritual needs of the younger generation;

- combined with arts and crafts, national costume, oral folklore, folk music facilitates forming an educational environment aimed at improving the student's personality;

- it is used in courses of music and art, culture of the native land, as well as in various forms of students' extracurricular and leisure activities, it also has didactic and educational potential.

We'd like to add that ethnocultural musicology is interdisciplinary, as its subject matter is often multimodal: sound, gesture, dance, and visual components are combined in order to produce and convey the essence of most musical cultures.

We are convinced that as a result of professional training to implement ethnocultural approach into the educational process the students - future musical art teachers - should be aware of the theory and practice of ethno-musical education (based on domestic musical folklore and music of peoples living in the region); peculiarities of folk music; technologies of mastering folk music at school. 
There is no doubt that future musical art teachers should be familiarized with the essence of the ethnocultural approach to music education of schoolchildren, features of its realization in practice during ethno-musical education. We find it important for students to understand basic concepts, provisions, purpose, tasks, principles, content of ethno-musical education, programs for general secondary education institutions that reflect the national component of music education, special literature on this issue.

Future musical art teachers' training is aimed at shaping students' views on the importance of ethno-musical culture in the formation of patriotism, tolerance, ethnic identity, ability to interethnic and intercultural communication as well as a place of ethno-musical culture in the system of national and world culture. Future musical art teachers should be aware of the relationships between folk music culture and world culture, their unique and universal features. In addition, knowledge of historical, natural, socio-cultural conditions that have influenced and continue to influence formation of folk music, in our opinion, helps deeper understand the essence of the ethnocultural approach.

We believe that in the process of professional training on the basis of the ethnocultural approach a special place belongs to the features of musical folklore as a special branch of musical art that reflects people's worldview, their spiritual and aesthetic ideals, ethno-musical psycho-semantics, its role in understanding folk music art. It is indisputable that implementation of the ethnocultural approach in future musical art teachers training can't be complete without knowledge on ethnic originality of musical language, genres of musical art of different nations, works of musical folklore (of Ukrainian people and peoples living in the country), which can be used in the practice of secondary school; features of folk singing style, methods, and techniques of its formation, methods of forming skills of polyphonic singing, improvisation and variation of melodies, dramatization of folk songs; types of folk dance movements (of Ukrainian people and peoples living in the country); folk instruments available for mass use in school practice, methods of playing them.

Outlining the structure of personal ethno-musical culture, ways of its formation basics of ethnomusical psychology, strategies of ethno-musical development of the personality, essential characteristics of ethno-musical hearing, ethno-musical thinking, memory, consciousness, in our opinion, will enhance the training of the future musical art teachers on the basis of the ethnocultural approach.

As a result of studying at pedagogical $\mathrm{HEI}$ on the ethnocultural basis future musical art teachers should have developed skills of using ethno-oriented music-pedagogical technologies at music lessons and in extracurricular activities based on the principles of cultural creativity, dialogue, as well as methods of developing ethno-musical abilities, teaching schoolchildren folk songs, organizing folklore games, perceiving works of musical folklore, playing folk musical instruments, using national dance movements.

One more important for future musical art teacher skill is the ability to characterize the main provisions of the ethnocultural approach to music education, goals, objectives, principles, content of ethno-musical education, to comprehend and use in practice special literature. An important stage in implementing the ethnocultural approach in future musical art teachers training is teaching students to organize and plan ethno-musical education taking into account the acquired knowledge and goals, curriculum for secondary schools, which reflects the national-regional components of music education.

It is also expedient to teach students to intone, "play" folk songs, vary, compose undertones in line with a particular folk song tradition, intone polyphonic songs, perform national dance movements, play the simplest folk musical instruments; to learn folk songs with children, to "play" them with the use of figurative and dance movements, to work on the folk song style of singing, to develop 
performing and creative skills, skills of variation and improvisation; to organize the process of listening to folk songs and tunes, the process of learning to play the simplest folk instruments; to involve children in musical folklore games.

We'd like to emphasize that other important skills include compiling summaries of music lessons with the use of musical folklore, scenarios of folklore holidays; using information and communication technologies in ethno-oriented music-educational work; carrying out psychological and pedagogical diagnostics of ethnomusical abilities, the level of ethno-musical culture development and correcting their own music-pedagogical activity according to the received results.

Taking into account the above mentioned, we see the purpose of training future musical art teachers to implement an ethnocultural approach in promoting students' citizenship, patriotism, tolerance, cultivating interest and love for folk music culture, forming ethno-musical and pedagogical competence.

Thus, we can state that the use of the ethnocultural approach in the future musical art teachers professional training can solve two main tasks:

1) developing students' stable cognitive interest in national music (both education and upbringing should be directed in such a way that in the future they could arouse similar interest in schoolchildren);

2) expanding students' musical horizons.

We agree with the opinion of domestic researcher A. Kozyr, who notes that national orientation of future musical art teachers training is manifested in higher spheres of professional mastery, such as formation of future teachers' spirituality, their value orientations (aesthetic ideals, artistic and musical tastes, ethnopedagogical priorities), and in the specifics of teaching music-pedagogical disciplines (using national musical art samples as learning repertoire, studying the experience of domestic masters of music-pedagogical work) (Kozyr, 2018, pp. 40-41).

The scientist believes that the search for innovative technologies in the field of theory and methods of teaching, as well as revival and creative rethinking of the rich experience of Ukrainian people, contributes to shaping students' national orientation. It is expedient to direct students' national orientation by complicating the task of aesthetic evaluation of the surrounding reality, which comprehensively covers the future teacher's knowledge of him/herself. This work should be carried out by involving students in various types of musical and aesthetic activities, especially in the thorough study of various works of national musical art (Kozyr, 2018, p. 41).

Implementation of the ethnocultural approach in the future musical art teachers professional training can take place in courses of historical-theoretical and methodological cycles, especially during the study of such disciplines as "Musical local lore", "Methods of music education", "Cultural resources of Ukraine", "Historical and cultural resources of Ukraine", "Methods of music upbringing", "History of Ukrainian music", etc.

The study of the academic programs allowed to assert that the ethnocultural context of future musical art teachers training is aimed at personality-centered organization of teaching and learning, professional integrity, formation of a musical art teacher in practical activities.

In our study, we'll consider the course "Musical local lore", which students attend during their fourth year of study at Sumy State Pedagogical University named after A. S. Makarenko. The main task of this discipline is formation of students' ideas about folklore as a special method of thinking. The course offers identification of the most common, typological features of folklore of different peoples. We believe that study of domestic folklore, presented in the thematic plan of this course as a special 
section, should be given special attention: it is important to study and analyze a number of works of Ukrainian song folklore in order to form students' skills and abilities to work with musical material as well as form the need in communication with works of domestic music and song folklore.

In addition, a large section should be occupied by the ethnocultural component in the disciplines aimed at studying the history of music, namely domestic. Thus, this section should include, in our opinion, a series of classes on the topic: "Musical culture of Ukraine: retrospective analysis". This cycle is designed to expand and supplement students' knowledge in the field of theory and history of national culture. Its purpose is an in-depth study of the history of the country's musical culture as an integral part of the spiritual heritage.

Analysis of the curriculum for students majoring in specialty 014 Secondary Education (Musical Art) allowed us to state that the basis of the program is constituted by several interrelated components: cultural-historical, historical-pedagogical, and methodological. Thus, the culturalhistorical component involves the study of the main events in the history of Ukrainian culture, peculiarities of its formation, as well as driving forces of cultural progress in the country.

The historical-pedagogical component envisages the study of the regional musical and pedagogical heritage: experience of involving students in music in the folk environment and education institutions of various types, activities of outstanding teachers and musicians of the region; includes an analysis of the factors that influenced the development of music culture in Ukraine.

The methodological component is aimed at studying different ways of mastering the musical and cultural heritage of Ukraine. Inclusion of national melodies, for example, in the subject "Solfeggio" will serve as useful material for the formation of intonation skills, analysis of melodic constructions (phrases, sentences, periods), development of students' musical hearing, ability to independently understand melodic structures of the studied works. National music should be widely used in the educational repertoire in vocals, conducting, the main musical instrument. We are convinced that it is expedient to include Ukrainian folk music and works by composers of other Slavic peoples in the programs of the courses "Analysis of Musical Works" and "Choral Class".

We'd like to emphasize that for improving the ethnocultural orientation of the process of future musical art teachers' professional training it is necessary to engage students in meaningful dialogues with imaginary historical figures of the music culture of the region. The study of national Ukrainian art from these positions not only stimulates student's creative activity but also orients him/her towards revealing distinctive features of national character and culture of the Ukrainian people, richness of musical language. All these contribute to the formation of the national identity, students' value attitudes to the national cultural heritage.

We'd like to note that during the implementation of the ethnocultural approach in future musical art teachers professional training it will be appropriate to effectively use various forms of ethno-musical activities, namely: improvisation, variation of musical material, independent creation of musical samples, solving ethnopedagogical problems of educational process; creation of original methodological support on the basis of methods and means of Ukrainian ethnopedagogy.

We agree with Yu. Yutsevych that Ukrainian national vocal tradition is conditioned by many factors: mentality, specifics of psychology, temperament, tastes, phonetic structure of speech, preferences, dreams - all the diversity of people's lives. A Ukrainian folk song is characterized by a gradual, almost devoid of significant jumps movement of the melody, which determines the development of a voice close to the Italian belcanto (Yutsevych, 1998, p. 132). Therefore, we consider it necessary to include Ukrainian folk songs, works of the school pedagogical repertoire in the learning repertoire of students, which they will use in their own practical activities. This statement is proved by 
the view of E. Makarova and V. Yakovenko that in the process of studying and performing Ukrainian folk songs students acquire not only vocal and technical skills but also knowledge about the history and culture of Ukraine, which forms in them a sense of national pride and respect for the glorious past of its people (Makarova \& Yakovenko, 2016, p. 137).

It should be noted that the implementation of the ethnocultural approach involves using the works of folk music in professional music training. In our opinion, this makes it possible to intensify the educational process, to make it more attractive, more interesting, to facilitate the acquisition of theoretical knowledge in music-theoretical disciplines and practical skills. Therefore, the process of future musical art teachers professional training on the ethnocultural basis will allow providing future musical art teachers with innovative technologies of teaching and upbringing, collecting, reporting and research of folk music creativity, deep rethinking, evaluation and promotion of folk art and national values inherent in it.

We'd like to stress that in the process of choosing the best samples of folk musical art it is necessary to adhere to the important principles of their high content and artistic quality, correspondence to the requirements of curriculum and accessibility for students.

As a result of the analysis of scientific artistic and psychological-pedagogical literature on the issue under investigation we can state that effectiveness of the ethnocultural approach in the process of future musical art teachers professional training is provided taking into account certain pedagogical conditions, in particular:

- organization of students' interdependent classroom and extracurricular activities;

- realization of interdisciplinary links during the development of the ethnocultural component of the content of music education;

- creation of ethno-musical educational environment;

- use of design, game, information and communication, ethnomusical technologies;

- implementation of joint activities of students and teachers, involving the older generation to study the music of their people and other peoples.

\section{Results}

As a result of the analysis of scientific literature, the curriculum for the specialty 014 Secondary Education (Musical Art), practical activities, we have revealed the theoretical and methodological foundations of ethnocultural approach in the process of future musical art teachers professional training:

- ethnocultural direction of the educational process of specialists in art education as one of the components of the new education paradigm;

- orientation of the process of future musical art teachers' professional training towards retransmission to the younger generation of folk music culture;

- taking into account the developmental potential of folk music in the process of future musical art teachers professional training;

- development of ethno-musical education;

- formation of students' professional skills on an ethnocultural basis;

- using national samples of musical art as learning repertoire; 
- involving students in various types of musical and aesthetic activities, especially in the study of various works of national musical art;

- personality-centered organization of the educational process, professional integrity, the formation of a musical art teacher in the process of practical activities;

- inclusion of ethnocultural component in courses of historical-theoretical and methodological cycles;

- effective use of various forms of ethnomusical activity;

- use of folk musical artworks as learning material.

\section{Conclusion}

We are convinced that the development of the national repertoire is a necessity for improving the efficiency of teaching and learning. Only a teacher who has the necessary knowledge, skills, and experience in studying and performing national works, obtained in the process of professional training, will be able to make folk and professional music accessible and understandable for children.

Thus, implementation of the ethnocultural approach in the future musical art teachers' professional training will promote the formation of civic and patriotic consciousness, love for homeland, respect for ethnic groups living in the region, country and their cultures, tolerance, which in general will ensure the formation of future musical art teacher as a citizen, Ukrainian, representative of his/her region, ethnicity. There is no doubt that this approach will allow preserving, developing, and retransmitting to the younger generation the culture of the native people, the culture of peoples living in Ukraine in the context of world culture, which, in its turn, will promote the formation of ethnic identity, ethnocultural, multicultural, intercultural, religious identity, ability to dialogic interaction, intercultural communication and cooperation. In addition, implementation of the ethnocultural approach in future musical art teachers' training will provide a certain level of students' ethno-musical culture development, as well as ethno-musical and pedagogical competence, and along with the multicultural and intercultural approach ensure an organic combination of domestic professional music education with world, global education, provide a high standard of education in general.

\section{References}

Berezyuk, O. S. (2015). Methodological foundations of formation of ethonocultural competence of personality. Educational discourse, 3(11), 13-21.

Fedorova, S. N. (2006). Formig the future pedagogues' ethnocultural competence (D.Sc. thesis). Moscow.

Honcharenko, S. U. (2011). Ukrainian Pedagogical Encyclopedic Dictionary. Rivne.

Hurenko, O. I. (2005). Formation of ethnocultural competence of students of the pedagogical university in the conditions of polyethnic environment (Ph.D. thesis). Kharkiv.

Ivanova, T. V. (2005). Culturological training of the future teacher. Kyiv.

Karpushyna, L. P. (2010). Ethnocultural approach in education: in essence of the issue. Integration of education, 3.

Khoruzha, O. V. (2008). Ethnocultural education in the system of future music teachers professional training. Science and Youth, 3, 14-16. 
Kolesnykova, I. A., \& Tytova, O. V. (2005). Pedagogical praxeology. Moscow.

Kozyr, A. (2018). Ethnocultural context of future music and choreography teachers' training. Humanization of the educational process, 1 (87), 39-46.

Law of Ukraine "On complete general secondary education" (2020). Retrieved from: https://zakon.rada.gov.ua/laws/show/463-20\#Text.

Law of Ukraine "On education" (2017). Retrieved from: https://zakon.rada.gov.ua/laws/show/214519\#Text.

Lomov, B. F. (2003). Systematics in psychology.

Lu, L. (2014). Methods of forming future music teachers' ethnocultural competence in pedagogical universities of Ukraine and China (Ph.D. thesis abstract). Kyiv.

Makarova, E. V., \& Yakovenko, V. H. (2016). Ethnocultural approach to vocal training of future music teachers. Musical art in educational discourse, 1, 135-138.

Milanova, O. S. (2011). Formation of ethnocultural competence of bachelors of social work in the process of professional training in the higher education institution (Ph.D. thesis abstract). Stavropol.

Padalka, H. M. (2010). Pedagogics of art: Theory and methodic of art disciplines teaching. Kyiv.

Protsiuk, V. (2015). Culturological aspects of the future music teacher preparation. Current issues of the humanities, 12, 124-129.

Qiao, J. (2016). The essence of ethnocultural competence: theoretical aspect. Theoretical and methodological problems of education of children and students youth, 20(2), 297-306.

Sidelnyk, N. V. (2012). Forming the future history teachers' ethnocultural competence in the process of professional training (Ph.D. thesis abstract). Kyiv.

Sieriakova, S. B. (2002). Formation of ethnocultural competence of a teacher of additional education (PhD thesis). Novosibirsk.

Solyar, L. (2016). Competence approach to the problem of future musical art teachers' ethnocultural competence formation. Scientific Bulletin of V. O. Sukhomlynskyi MNU. Pedagogical Sciences, 1 (52), 118-122.

Solyar, L. (2018). Concrete scientific methodology of the problem of forming the future musical art teacher's ethnocultural competence. Pedagogical discourse, 24, 76-81.

$\mathrm{Xu}, \mathrm{T}$. (2017). Methodological principles of future music teachers ethnocultural preparation in the process of professional training (Ph.D. thesis). Kyiv.

Yutsevych, Yu. E. (1998). Theory and methods of singing voice development. Kyiv.

Zhyhinas, T. V. (2016). Axiological approach in preparing future music teachers for educational work. Spirituality of personality: methodology, theory and practice, 5(74), 85-94. 